\title{
Марија М. Јовановић 162
}

Универзитет у Нишу

Филозофски факултет у Нишу

\section{ИНДИВИДУАЛИЗАЦИЈА НАСТАВНЕ КОМУНИКАЦИЈЕ У ОСНОВНОШКОЛСКОЈ ПРАКСИ}

\begin{abstract}
Сажетак: Индивидуализација наставе као претпоставка обезбеђивања квалитета у планирању и реализацији циљева и задатака васпитања и образовања подразумева процесе прилагођавања дидактичко-методичких поступака индивидуалним особеностима ученика. Основу успешне индивидуализације наставе чини индивидуализација наставне комуникације као средства али и циља наставног рада. Рад има за циљ да утврди ставове наставника и ученика о томе да ли основношколску наставну праксу крактерише индивидуализаџија наставне комуникације. У раду су представљени резултати истраживања спроведеног на узорку од 550 ученика завршних разреда основне школе и 160 наставника са подручја Школске управе Ниш. На основу анализе утврђених резултата може се закључити да истраживану праксу не карактерише завидан ниво индивидуализације наставне комуникације, те да је у овој области потребна значајна педагошко-дидактичка интервенција и оснаживање свих актера наставног процеса.
\end{abstract}

Кључне речи: индивидуализација, настава, комуникација, основна школа, пракса.

\section{ТЕОРИЈСКИ ПРИСТУП}

Утемељена на разноврсним и често веома сложеним комуникационим моделима, настава квалитет и ефикасност нужно заснива на особеностима и квалитету остварених комуникационих форми. Сходно томе, сваки захтев усмерен ка обезбеђивању квалитетне и ефикасне наставе мора бити заснован на обезбеђивању услова за остваривање квалитетне и ефикасне комуникације у њој. Само квалитетним и ефикасним комуницирањем у настави и базирањем свих васпитно-образовних активности на начелима ефикасног комуницирања ствара се основа успешног наставног рада. Једна од нужних претпоставки квалитетне наставе јесте индивидуализација наставне комуникације, односно њено прилагођавање комуникативним способностима свих ученика у комуникацији. Комуникативна способност подразумева

162marija.jovanovic@filfak.ni.ac.rs 
способност прилагођавања разноврсним ситуацијама комуникације и обухвата знање, особине и навике комуницирања. Заснивање и оријентација комуникације ка реално присутним моделима и нивоима комуникативних способности ученика чини темељ обезбеђивања квалитета и ефикасности наставе. Осим оријентације ка реалним комуникативним способностима ученика, наставна комуникација мора бити усмерена и ка развојном моделу образовања, односно тако конципирана да на реалним могућностима гради систем васпитнообразовних поступака којима се подстиче и стимулише целовити развој ученикове личности. У том смислу, за „адекватан раст и развој, кооперативност и квалитетну интеракцију и комуникацију, односно пуну активност деце раног узраста неопходно је креирати ангажујуће, умно подстичуће, стимулативно и плодоносно окружење за учење, конкретнија високоефективна и за учење погодна окружења оријентисана ка детету" (Јовановић 2018: 13). Креирање оваквог окружења значи створити такве услове који ће свим ученицима без изузетка и сходно њиховим индивидуалним могућностима и капацитетима дати једнаке шансе и прилике за остваривање дефинисаних исхода образовања и несметани развој до највиших могућих граница. Како „исходи општег образовања доприносе укупном развоју личности и потенцијала ученика, његовом оспособљавању да се активно и одговорно укључи у друштвени живот и пружи, оствари свој удео у развоју друштва и културе" (Минић 2012: 186), њихово остваривање јесте једини пут реализације развојног модела образовања. Оптимални начин реализовања овог модела јесу индивидуализације свих васпитно-образовних активности које се реализују у настави.

Индивидуализација наставе као савремени приступ настави заснива се на уважавању индивидуалних капацитета ученика као и индивидуализацији поступака и путева учења и поучавања. Утемељена на индивидуалним разликама међу ученицима и усмерена на њихово подстицање и развој, индивидуализација наставе подразумева такву организацију наставних активности којима ће се сваком појединцу без изузетка, у складу с његовим индивидуалним могућностима омогућити оптимални наставни рад и субјекатска позиција у настави. Индивидуализација наставе се заснива на прихватању и уважавању реално постојећих разлика између ученика, разноврсности прилаза и поступака у наставном процесу и избору метода, средстава и материјала наставног рада у складу са непосредним, индивидуално дефинисаним наставним контекстом.

Индивидуализација наставне комуникације заснива се на низу њених кључних особености које нужно захтевају прилагођавање индивидуалним својствима њених учесника. Као основне особености из којих произлази захтев за индивидуализацију наставне комуникације издвајају се: денотативно и конотативно значење наставне комуникације, персонална обележеност, трансакциони и симболички карактер. 


\section{М. Јовановић}

Денотативно и конотативно значење наставне комуникације односи се на садржаје и учеснике комуникације чије усаглашавање чини основу разумевања у настави. Док се денотативно значење односи на једнозначне поруке и садржаје комуницирања у настави и обезбеђује заштиту од неразумевања и неспоразума, конотативно значење се односи на сложеније садржаје који имају имплицитно значење, а које је често извор неспоразума. Да би се у наставном процесу обезбедио висок ниво разумевања а имплицитна значења комуницирања свела на минимални ниво, неопходно је индивидуализовати наставну комуникацију. Основа индивидуализације наставне комуникације у домену денотативног и конотативног значења подразумева прилагођавање садржаја и начина комуницирања могућностима ученичког разумевања и интерпретирања порука и информација које наставна комуникација пружа.

Персонална обележеност наставне комуникације односи се на њено својство да се значења у процесу комуницирања налазе у људима а не у речима и симболима. Како током комуникације учесници врше кодирање и декодирање порука, квалитет и ефикасност ових процеса у великој мери зависе од индивидуализације процеса комуницирања у настави. Кодирање као „когнитивни мисаони процес трансформације идеја и осећања у симболе и њихово организовање у форми саопштења, и декодирање као процес трансформације саопштења у идеје и осећања" (Вердербер 2005: 21) чине да учесници наставне комуникације врше ове кључне процесе на себи својствен начин, дајући им властита обележја. У процесу комуникације садржај комуницирања може за различите особе имати различита значења. Значење у процесу комуникације настаје тек онда када појединац изврши интерпретацију поруке која му је послата. Карактеристика педагошког општења да сам прималац поруке утиче на њено значење и схватање смисла својим персоналним својствима даје педагошкој комуникацији персоналну обележеност. Из овако схваћене персоналне обележености наставне комуникакције произлази и основни захтев успешног комуницирања, а то је индивидуализација комуникационих процеса који се у настави остварују.

Трансакциони карактер педагошке комуникације подразумева једносмерност и двосмерност у процесу преношења садржаја између учесника комуникације, као и могућност измене улога. Да бисмо обезбедили адекватност трансакционог карактера комуникације нужно је индивидуализовати наставну комуникацију. Ако знамо да је најбитнија одлика индивидуализације наставе у непосредној наставној пракси „да се у дидактичко-методички различито обликованим ситуацијама током наставног процеса, у генези коришћених наставних система, ангажује цео дијапазон различитих могућности ученика и да то ангажовање, да би било благовремено, иде испред развоја, а не да заостаје за њим" (Ђукић 1995: 35), онда је јасно колико је важан овакав приступ у непосредној наставној комуникацији. Само се утемељивањем комуникационих односа 
на реалним капацитетима њених учесника обезбеђује завидан ниво трансакционог карактера наставне комуникације.

Симболички карактер педагошке комуникације односи се на процес слања поруке и процес интерпретације, односно декодирања поруке. У самом декодирању поруке налази се смисао педагошке комуникације. Уколико у комуникацији не дође до декодирања поруке, сигнала, речи, садржаја који су упућени ученику, комуникација остаје бесмислена. На основу реченог, закључује се да педагошка комуникација има и имплицитни (знаковни) и експлицитни (симболички) карактер и да је уравнотежавање ових својстава претпоставка њеног успеха. Да бисмо у наставној комуникацији извршили усаглашавање имплицитних и експлицитних значења важно је уважавати индивидуалне комуникативне способности и начине и садржаје комуницирања прилагодити овим карактеристикама сваког појединачног ученика.

\section{МЕТОД}

Циљ рада је да се емпиријским путем утврди да је индивидуализација наставне комуникације реалност или императив основношколске праксе. Задатак истраживања јесте испитати, анализирати и упоредити ставове ученика и наставника о индивидуализацији наставне комуникације у основној школи. Узорком је обухваћен укупно 550 ученика завршних разреда основношколског образовања и 160 наставника основних школа са подручја Школске управе Ниш.

табела 1: Структура испитаника према третираним варијаблама

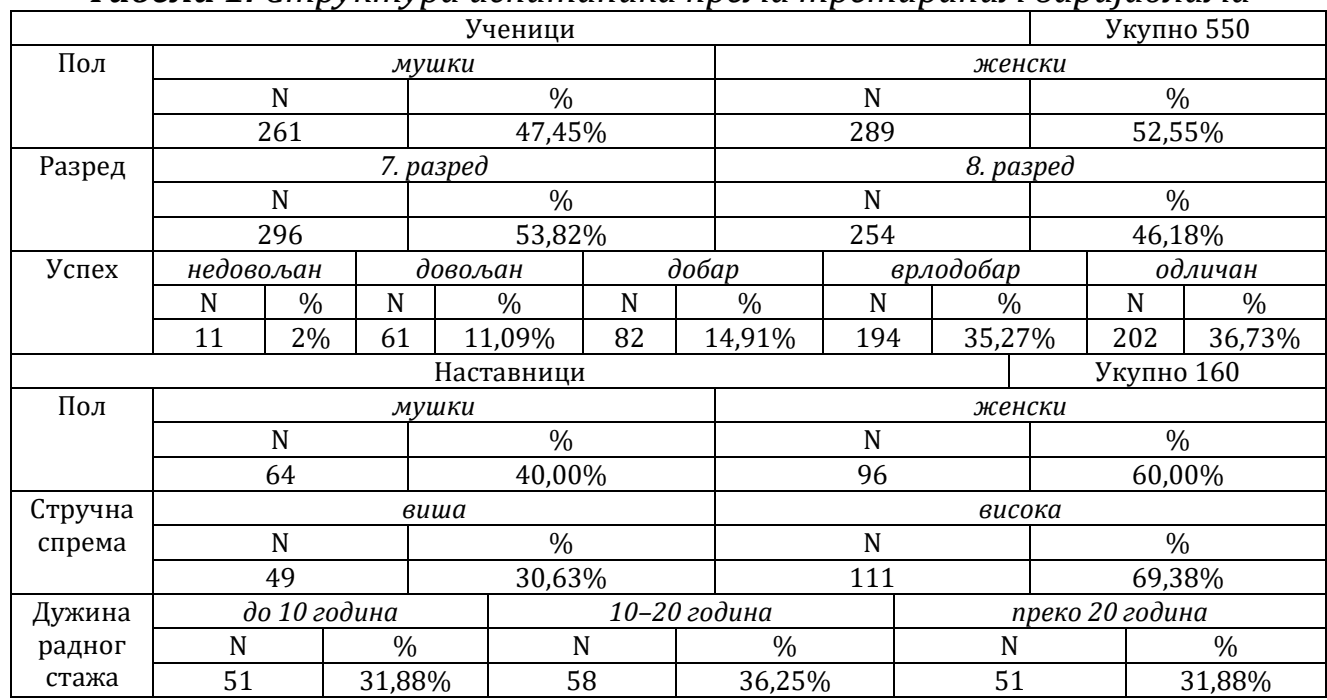




\section{М. Јовановић}

На основу приказане спецификације узорка у односу на третиране варијабле (Табела 1) може се закључити да постоји приближна уједначеност ученика у односу на пол и разред, као и да чак $72 \%$ испитаника чине ученици са врлодобрим и одличним успехом. Због малог узорка ученика са недовољним успехом (11; 2\%) за потребе овог истраживања и интерпретацију утврђених резултата извршено је спајање групе ученика с недовољним и довољним успехом. У групи наставника заступљенији је женски пол и испитаници с високим образовањем (60\% наспрам 40\%, односно 69,38\% наспрам 30,63\%). У односу на дужину радног стажа, присутна је значајана уједначеност броја испитаника.

\section{РЕЗУЛТАТИ ИСТРАЖИВАЊА - АНАЛИЗА И ИНТЕРПРЕТАЦИЈА ИНДИВИДУАЛИЗАЦИЈА НАСТАВНЕ КОМУНИКАЦИЈЕ}

табела 2: Ставови наставника и ученика о индивидуализацији наставне комуникације

\begin{tabular}{|c|c|c|c|c|}
\hline \multirow{2}{*}{$\begin{array}{l}\text { Комуникација у настави } \\
\text { прилагођена је } \\
\text { индивидуалним својствима } \\
\text { ученика }\end{array}$} & \multicolumn{2}{|c|}{ Ученици } & \multicolumn{2}{|c|}{ Наставници } \\
\hline & $\mathrm{N}$ & $\%$ & $\mathrm{~N}$ & $\%$ \\
\hline Прилагођена је & 102 & 18,55 & 46 & 28,75 \\
\hline Није прилагођена & 273 & 49,64 & 64 & 40,00 \\
\hline Делимично је прилагођена & 175 & 31,82 & 50 & 31,25 \\
\hline Укупно & 550 & 100,00 & 160 & 100,00 \\
\hline
\end{tabular}

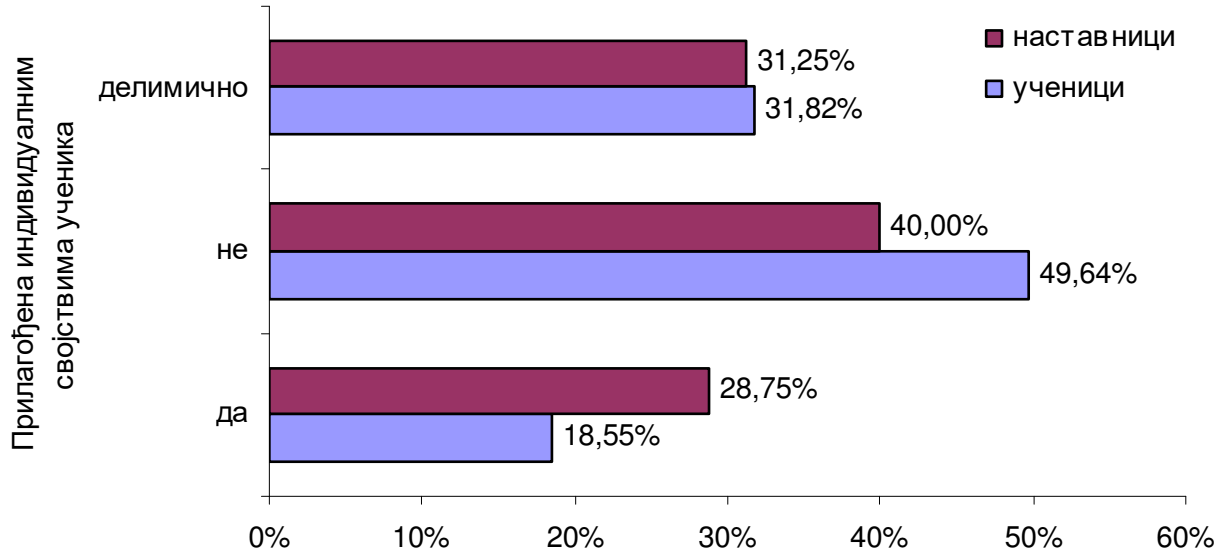

Графикон 1: Да ли је комуникација у настави прилагођена индивидуалним својствима ученика?

$$
\chi^{2}=8,629, \mathrm{df}=2, \mathrm{p}<0,05, \mathrm{C}=0,11
$$


Индивидуализација наставне комуникације подразумева њену прилагођеност индивидуалним својствима ученика. Резултати спроведеног истраживања показују постојање статистички значајне разлике између ставова наставника и ученика о овом питању: $\chi^{2}=8,629$, $\mathrm{df}=2, \mathrm{p}<0,05$. Добијени C-коефицијент контингенције $(\mathrm{C}=0,11)$ показује врло слабу повезаност, односно незнатну корелацију. У обе групе је најчешћи негативан одговор, што говори о томе да и наставници и ученици сматрају, пре свега, да наставна комуникација није прилагођена индивидуалним својствима ученика. У групи ученика негативан одговор (273; 49,64\%) статистички је значајнији у односу на оба друга одговора понаособ (прилагођена је - 102; 18,55\% и делимично је прилагођена $175 ; 31,82 \%)$, док је код наставника овај одговор (40,00\%) статистички учесталији само у односу на позитиван став (28,65\%). Приметно је да се око трећина испитаника у обе групе одлучила за одговор да је комуникација у настави делимично прилагођена индивидуалним својствима ученика (ученици - 31,82\%, наставници - 31,25\%). Међутим, поређењем појединачних одговора у свакој групи испитаника понаособ код наставника је израженији позитиван одговор (p < 0,01), а код ученика негативан $(\mathrm{p}<0,05)$.

Без обзира на постојање разлика у ставовима ученика и наставника по овом питању, резултати недвосмислено показују да се у основношколској пракси врши недовољна индивидуализација наставне комуникације. О томе на исти начин сведоче сви актери овог процеса. Као разлог за ово можемо навести чињеницу да је комуникација у настави оптерећена великим бројем ученика у разреду (и преко 30 ученика), те је самим тим индивидуализација отежана па често и потпуно немогућа. Такође, с обзиром на то да је у настави наглашен пре свега образовни задатак, његово остваривање намеће комуникацији низ обележја која су у супротности са персоналном димензијом, па самим тим и са њеном индивидуализацијом. Оптерећеност наставне комуникације великим бројем ученика и унапред дефинисаним и униформним циљевима и прописаним наставним садржајем (обимним) доводе до тога да се индивидуализација наставне комуникације у пракси у недовољној мери остварује.

табела 3: Ставови наставника и ученика о индивидуализацији наставне комуникације (у односу на пол)

\begin{tabular}{|c|c|c|c|c|c|c|c|c|}
\hline \multirow{2}{*}{$\begin{array}{l}\text { Комуникација у настави прилагођена } \\
\text { индивидуалним својствима ученика }\end{array}$} & \multicolumn{2}{|c|}{ Уч. мушки } & \multicolumn{2}{|c|}{ Уч. женски } & \multicolumn{2}{|c|}{ Наст. мушки } & \multicolumn{2}{|c|}{ Наст. женски } \\
\hline & $\mathrm{N}$ & $\%$ & $\mathrm{~N}$ & $\%$ & $\mathrm{~N}$ & $\%$ & $\mathrm{~N}$ & $\%$ \\
\hline Прилагођена је & 55 & 21,07 & 47 & 16,26 & 18 & 28,13 & 28 & 29,17 \\
\hline Није прилагођена & 134 & 51,34 & 139 & 48,10 & 29 & 45,31 & 35 & 36,46 \\
\hline Делимично је прилагођена & 72 & 27,59 & 103 & 35,64 & 17 & 26,56 & 33 & 34,38 \\
\hline Укупно & 261 & 100,00 & 289 & 100,00 & 64 & 100,00 & 96 & 100,00 \\
\hline
\end{tabular}

Ученици: $\chi^{2}=4,797, \mathrm{df}=2, \mathrm{p}=0,09, \mathrm{C}=0,09$

Наставници: $\chi^{2}=1,517, \mathrm{df}=2, \mathrm{p}=0,468, \mathrm{C}=0,1$ 


\section{М. Јовановић}

Из Табеле 3 се може видети да пол ученика није утицао на њихове одговоре о индивидуализацији наставне комуникације. Без обзира на пол ученици у највећем броју сматрају да наставна комуникација није прилагођена индивидуалним својствима ученика (ж. пол - 48,1\%, м. пол $51,34 \%$ ), те да се у њој не врши индивидуализација. Девојчице значајно чешће истичу њено делимично остваривање $(35,64 \%)$ у односу на дечаке $(27,59 \%)$. Добијени C-коефицијент контингенције ( $C=0,09)$ показује да корелација не постоји. Код наставника, такође, није утврђена статистички значајна разлика у односу на пол по овом питању: $\chi^{2}=1,517$, $\mathrm{df}=2, \mathrm{p}=0,468$. Као и ученици, тако и наставници најчешће сматрају да наставна комуникција није индивидуализована (ж. пол - 36,46\%, м. пол $45,31 \%)$, док најмањи број њих потврђује њено остваривање (ж. пол $29,17 \%$, м. пол - 28,13\%). Добијени С-коефицијент контингенције (C = 0,1) говори о врло слабој повезаности, односно незнатној корелацији.

табела 4: Ставови наставника и ученика о индивидуализацији наставне комуникације (у односу на локацију школе)

\begin{tabular}{|c|c|c|c|c|c|c|c|c|}
\hline \multirow{2}{*}{$\begin{array}{l}\text { Комуникација у настави } \\
\text { прилагођена } \\
\text { индивидуалним } \\
\text { својствима ученика }\end{array}$} & \multicolumn{2}{|c|}{$\begin{array}{c}\text { Ученици } \\
\text { градска школа }\end{array}$} & \multicolumn{2}{|c|}{$\begin{array}{c}\text { Ученици } \\
\text { приградска школа } \\
\end{array}$} & \multicolumn{2}{|c|}{$\begin{array}{c}\text { Наставници } \\
\text { градска школа }\end{array}$} & \multicolumn{2}{|c|}{$\begin{array}{c}\text { Наставници } \\
\text { приградска школа }\end{array}$} \\
\hline & $\mathrm{N}$ & $\%$ & $\mathrm{~N}$ & $\%$ & $\mathrm{~N}$ & $\%$ & $\mathrm{~N}$ & $\%$ \\
\hline Прилагођена је & 47 & 18,01 & 55 & 19,03 & 25 & 31,25 & 21 & 26,25 \\
\hline Није прилагођена & 136 & 52,11 & 137 & 47,40 & 31 & 38,75 & 33 & 41,25 \\
\hline $\begin{array}{l}\text { Делимично је } \\
\text { прилагођена }\end{array}$ & 78 & 29,89 & 97 & 33,56 & 24 & 30,00 & 26 & 32,50 \\
\hline Укупно & 261 & 100,00 & 289 & 100,00 & 80 & 31,25 & 80 & 26,25 \\
\hline
\end{tabular}

Ученици: $\chi^{2}=1,272, \mathrm{df}=2, \mathrm{p}=0,529, \mathrm{C}=0,05$

Наставници: $\chi^{2}=0,49, \mathrm{df}=2, \mathrm{p}=0,783, \mathrm{C}=0,05$

Анализа представљених резултата показује да локација школе није утицала на различитост ставова нити ученика: $\chi^{2}=1,272, \mathrm{df}=2, \mathrm{p}=0,529$, нити наставника: $\chi^{2}=0,49, \mathrm{df}=2, \mathrm{p}=0,783$.

У обе групе испитаника доминира став да наставна комуникација није прилагођена индивидуалним својствима ученика (ученици градска школа- 52,11\%, ученици приградска школа- 47,74\%, наставници градска школа - 38,75\%, наставници приградска школа - 41,25\%).

Ученици обе средине на друго место истичу да је комуникација делимично прилагођена (ученици градска школа - 29,89\%, ученици приградска школа - 33,56\% ), а на последње место да је она прилагођена персоналним својствима ученика (ученици градска школа - 18,01\%, ученици приградска школа - 19,03\%). Приметно је да се наставници из градске средине нешто чешће од својих колега из приградске средине одлучују за потврдан одговор (31,25\% у односу на 26,25\%). У обе групе испитаника добијени С-коефицијент контингенције (C =0,05 и С =0,05) показује да корелација не постоји. 
Табела 5: Ставови ученика о индивидуализацији наставне комуникације (у односу на узраст ученика)

\begin{tabular}{|l|r|r|r|r|}
\hline Комуникација у настави прилагођена & \multicolumn{2}{|c|}{ 7. разред } & \multicolumn{2}{|c|}{ 8. разред } \\
\cline { 2 - 5 } индивидуалним својствима ученика & $\mathrm{N}$ & $\%$ & $\mathrm{~N}$ & $\%$ \\
\hline Прилагођена је & 57 & 19,26 & 45 & 17,72 \\
\hline Није прилагођена & 147 & 49,66 & 126 & 49,61 \\
\hline Делимично је прилагођена & 92 & 31,08 & 83 & 32,68 \\
\hline Укупно & 296 & 100,00 & 254 & 100,00 \\
\hline
\end{tabular}

$$
\chi^{2}=0,284, \mathrm{df}=2, \mathrm{p}=0,867, \mathrm{C}=0,02
$$

Ставове ученика о индивидуализацији наставне комуникације узраст није детерминисао: $\chi^{2}=0,284$, df $=2, \mathrm{p}=0,867$. Добијени Cкоефицијент контингенције $(C=0,02)$ показује да корелација не постоји. Према учесталости одговора утврђен је следећи ранг: 1. наставна комуникација није прилагођена персоналним својствима ученика (7. р. 49,66\%, 8. p. - 49,61\%); 2. наставна комуникација је делимично прилагођена персоналним својствима ученика (7. р. - 31,08\%, 8. p. $32,68 \%) ; 3$. наставна комуникација је прилагођена персоналним својствима ученика (7. p. - 19,26\%, 8. p. - 17,72\%).

табела 6: Ставови наставника и ученика о индивидуализацији наставне комуникације (у односу на успех ученика)

\begin{tabular}{|c|c|c|c|c|c|c|c|c|}
\hline \multirow{2}{*}{$\begin{array}{l}\text { Комуникација у настави } \\
\text { прилагођена индивидуалним } \\
\text { својствима ученика }\end{array}$} & \multicolumn{2}{|c|}{$\begin{array}{c}\text { Одличан } \\
\text { успех }\end{array}$} & \multicolumn{2}{|c|}{$\begin{array}{c}\text { Врлодобар } \\
\text { успех }\end{array}$} & \multicolumn{2}{|c|}{$\begin{array}{l}\text { Добар } \\
\text { успех }\end{array}$} & \multicolumn{2}{|c|}{$\begin{array}{c}\text { Довољан и } \\
\text { недовољан успех }\end{array}$} \\
\hline & $\mathrm{N}$ & $\%$ & $\mathrm{~N}$ & $\%$ & $\mathrm{~N}$ & $\%$ & $\mathrm{~N}$ & $\%$ \\
\hline Прилагођена је & 48 & 23,76 & 30 & 15,46 & 14 & 17,07 & 10 & 13,89 \\
\hline Није прилагођена & 95 & 47,03 & 102 & 52,58 & 36 & 43,90 & 40 & 55,56 \\
\hline Делимично је прилагођена & 59 & 29,21 & 62 & 31,96 & 32 & 39,02 & 22 & 30,56 \\
\hline Укупно & 202 & 100,00 & 194 & 100,00 & 82 & 100,00 & 72 & 100,00 \\
\hline
\end{tabular}

$$
\chi^{2}=8,370, \mathrm{df}=6, \mathrm{p}=0,212, \mathrm{C}=0,12
$$

Успех ученика није значајно утицао на одговоре ученика на ово питање: $\chi^{2}=8,370, \mathrm{df}=6, \mathrm{p}=0,212$. Негативан одговор преовладава код свих ученика, с тим да се са падом успеха повећава број оних који дају овакав одговор (одлични - 47,03\%, довољни и недовољни - 55,56\%). Насупрот овоме, број ученика који сматрају да је комуникација прилагођена индивидуалним својствима ученика повећава се са бољим успехом ученика (недовољни и довољни - 13,89\%, одлични - 23,76\%). Добијени С-коефицијент контингенције $(\mathrm{C}=0,12)$ говори о врло слабој повезаности, односно незнатној корелацији. 
табела 7: Ставови наставника о индивидуализацији наставне комуниакције ( у односу на стручну спрему наставника)

\begin{tabular}{|l|r|r|r|r|}
\hline \multirow{2}{*}{$\begin{array}{l}\text { Комуникација у настави } \\
\text { прилагођена индивидуалним } \\
\text { својствима ученика }\end{array}$} & \multicolumn{2}{|c|}{ Виша с.с. } & \multicolumn{2}{|c|}{ Висока с.с. } \\
\cline { 2 - 6 } Прилагођена је & 16 & \multicolumn{1}{c|}{$\%$} & \multicolumn{1}{c|}{$\mathrm{N}$} & \multicolumn{1}{c|}{$\%$} \\
\hline Није прилагођена & 17 & 34,65 & 30 & 27,03 \\
\hline Делимично је прилагођена & 16 & 32,65 & 34 & 42,34 \\
\hline Укупно & 49 & 100,00 & 111 & 100,00 \\
\hline
\end{tabular}

$$
\chi^{2}=0,916, \mathrm{df}=2, \mathrm{p}=0,663, \mathrm{C}=0,07
$$

Истраживањем није утврђена статистички значајна разлика ни у односу на степен стручне спреме наставника: $\chi^{2}=0,916, \mathrm{df}=2, \mathrm{p}=0,663$. Cкоефицијент контингенције $(C=0,07)$ указује да корелација не постоји. Највећи број наставника истиче негативан одговор (виша с.с. - 34,69\%, висока с.с. - 42,34\%). Приметно је, такође, да се наставници са вишом стручном спремом у једнаком броју изјашњавају за остваривање и делимично остваривање индивидуализације у наставној комуникацији (по 32,65\%), док наставници из приградске средине дају малу предност делимичном остваривању.

табела 8: Ставови наставника о индивидуализацији наставне комуниакције (у односу на дужину радног стажа)

\begin{tabular}{|c|c|c|c|c|c|c|}
\hline \multirow{2}{*}{$\begin{array}{l}\text { Комуникација у настави } \\
\text { прилагођена индивидуалним } \\
\text { својствима ученика }\end{array}$} & \multicolumn{2}{|c|}{$\begin{array}{c}\text { Радни стаж } \\
1-10 \text { год. } \\
\end{array}$} & \multicolumn{2}{|c|}{$\begin{array}{c}\text { Радни стаж } \\
11-20 \text { год. }\end{array}$} & \multicolumn{2}{|c|}{$\begin{array}{c}\text { Радни стаж } \\
\text { 21-30 год. } \\
\end{array}$} \\
\hline & $\mathrm{N}$ & $\%$ & $\mathrm{~N}$ & $\%$ & $\mathrm{~N}$ & $\%$ \\
\hline Прилагођена је & 15 & 29,41 & 18 & 31,03 & 13 & 25,49 \\
\hline Није прилагођена & 18 & 35,29 & 25 & 43,10 & 21 & 41,18 \\
\hline Делимично је прилагођена & 18 & 35,29 & 15 & 25,86 & 17 & 33,33 \\
\hline Укупно & 51 & 100,00 & 58 & 100,00 & 51 & 100,00 \\
\hline
\end{tabular}

$$
\chi^{2}=1,618, \mathrm{df}=4, \mathrm{p}=0,806, \mathrm{C}=0,1
$$

Дужина радног стажа наставника није у значајној мери детерминисала различитост одговора наставника на ово питање: $\chi^{2}=$ $1,618, \mathrm{df}=4, \mathrm{p}=0,806$. Добијени С-коефицијент контингенције $(\mathrm{C}=0,1)$ говори о врло слабој повезаности, односно незнатној корелацији. Највећи део наставника одговорио је да наставна комуникација није прилагођена индивидуалним својствима ученика (1-10 г. - 35,29\%, 11-20 г. -43,10\%, 21-30 г. $-41,18 \%)$.

\section{ЗАКЉУЧАК}

Савремена основна школа и њена оријентација ка развојном моделу образовања подразумева такву организацију наставних активности којима ће се ученици и њихови индивидуални капацитети и особености третирати као полазна основа али и крајњи циљ наставе. Усмерен на 
развој личности сваког појединачног ученика и актуелизацију индивидуалних капацитета, савремени приступ наставе заснива се на индивидуализацији наставних активности и то како у смислу уважавања индивидуалних капацитета ученик,а тако и у смислу индивидуализације поступака и путева поучавања и учења.

Карактеристике савремене основне школе почивају на захтеву да све активности у настави треба усмерити ка откривању и развоју индивидуалних интелектуалних и стваралачких потенцијала сваког појединачног ученика и стварање услова у којима ће се индивидуални потенцијали оптимално реализовати и усавршавати. Основно средство остваривања, али и крајњи циљ ове наставне оријентације јесте индивидуализација наставне комуникације.

Интерпретацијом резултата спроведеног истраживања утврђено је да основношколску праксу не карактерише значајан ниво индивидуализације наставне комуникације. Иако и наставници и ученици најчешће истичу да наставна комуникација није индивидуализована, односно прилагођена индивидуалним капацитетима ученика, утврђено је постојање разлике у ставовима наставника и ученика по овом питању. Уочена разлика последица је нешто веће умерености наставника у изношењу негативног става по овом питању.

На основу добијених резултата може се закључити да индивидуализација наставне комуникације није реалност основношколске праксе већ њен императив. Разлоге уочене појаве можемо повезати са великим бројем ученика у одељењу и обимним наставним програмима који у значајној мери утичу на могућности и квалитет индивидуализације наставних активности. Ипак, важно је напоменути да идентификовани узроци утврђених појава нису и не смеју бити оправдање, већ би требало послужити као важан податак за унапређивање и превазилажење уочених недостатака. Резултати недвосмислено указују на неопходност педагошко-дидактичке интервенције и оснаживања свих актера наставног процеса у овој области. Едукација наставника у области развоја професионалних компетенција педагошке комуникације али и дидактичко-методичких компетенција услов су за превазилажење уоченог стања основношколске праксе. Савладавањем техника, метода и врста успешне наставне комуникације и вештина интерактивног дидактичко-методичког обликовања наставног рада може се извршити компетентно оснаживање свих актера наставне комуникације да иманентно индивидуалним могућностима ученика остварују квалитетну наставну комуникацију. Такође, утврђени резултати могу послужити као основа за даља истраживања усмерена на утврђивање образовних потреба наставника али и реалних капацитета ученика, којима се може унапредити истраживана пракса у домену индивидуализације наставне комуникације. 


\section{ЛИТЕРАТУРА}

Будић, Споменка. Индивидуализована настава и успех ученика. Нови Сад: Савез педагошких друштава Војводине, 1999.

Вердербер, Рудольф, Кэтлин, Вердербер. Общение - интенсивний курс. Москва: „Олма-пресс”, 2005.

Biesta, Gert. Education/Communication: The Two Faces of Communicative Pedagogy. (C)1996-2004 Philosophy of education society all rights reserved, 2005.

Glasser, William. Наставнику квалитетној школи. Загреб: Едука, 1999.

Ђорђевић, Јован. Индивидуализација и иновирање наставе и учења у школи 21. века. Педагошка стварност, 7-8 (2009): 673-685.

Ђукић, Мара. Дидактички чиниоци индивидуализоване наставе. Нови Сад: Филозофски факултет, 1995.

Ђукић, Мара. Психолошке основе индивидуализације наставе. Норма, 1/1 (1995): 42 52.

Carlgrena, Ingrid, Kirsti Klette, Sigurjo'n My'rdal, Karsten Schnackd and Hannu Simolae: From individualised teaching to the teaching of individuals. Scandinavian Journal of Educational Research, 50/3 (2006): 301-326.

Јовановић, Драгана. Подстицајна клима за учење и лидерство васпитача; Слободанка Радосављевић (ур.). Средина за учење - извор грађења односа, интегрисаност учења и богаћења искустава детета. Смедерево: NewPress, 2018.

Минић, Весна. Основно образовање у Србији у другој половини ХХ века. Лепосавић: Учитељски факултет у Призрену - Лепосавић, 2012.

Obisat, Farhan, Ezz Hattab. A proposed model for individualized learning through mobile technologies. International Journal of Computers, 1/3 (2009): 103-118.

Reter, Hein. Studienbuch pedagogische komunikation. Bad Heilbrunn: Julius Klinkhardt, 2000.

Шпановић, Светлана. Индивидуализована настава у теорији и пракси. Настава и васпитање, 60/3 (2011): 500-514

\section{INDIVIDUALIZING CLASSROOM COMMUNICATION IN PRIMARY SCHOOL}

Abstract: Individualization of instruction as a precondition for quality assurance in planning and achieving learning goals and objectives implies the adaptation of methodology and didactic procedures to individual student characteristics. The basis of successful individualized instruction is the individualization of classroom communication as a means but also a goal of education. This paper aims to determine the opinions of teachers and students on whether primary school education is characterized by individualized classroom communication. The paper presents the results of a study conducted on a sample of 550 students in the final grades of primary school and 160 teachers from the School Administration of Nis. Based on the analysis of the survey results, it can be concluded that the primary schools analyzed in our study are not characterized by an enviable level of individualized classroom communication and that a significant pedagogic and didactic intervention and development of all participants in the learning process is needed in this field.

Key words: individualization, teaching, communication, primary school, practice. 